PENANGGUNG JAWAB

Dekan Fakultas Ilmu Tarbiyah dan Keguruan

REVIEWER

Ani Cahyadi

Universitas Islam Negeri Antasari Banjarmasin, Indonesia

Imam Rofiki

Universitas Islam Negeri Maulana Malik Ibrahim Malang, Indonesia

Nuril Mufidah

Universitas Islam Negeri Maulana Malik Ibrahim Malang, Indonesia

Nuri Wuryandani

Universitas Negeri Yogyakarta, Indonesia

Muhammad Walid

Universitas Islam Negeri Maulana Malik Ibrahim Malang, Indonesia

Wahid Murni

Universitas Islam Negeri Maulana Malik Ibrahim Malang, Indonesia

EDITOR IN CHIEF

M. Irfan Islamy

Universitas Islam Negeri Maulana Malik Ibrahim Malang, Indonesia

SECTION EDITOR

Abdul Fattah

Universitas Islam Negeri Maulana Malik Ibrahim Malang, Indonesia

Galih Puji Mulyanto

Universitas Islam Negeri Maulana Malik Ibrahim Malang, Indonesia

Dewi Nur Suci

Sekolah Tinggi Agama Islam Kediri, Indonesia

Dwi Sulistiani

Universitas Islam Negeri Maulana Malik Ibrahim Malang, Indonesia

LAYOUT EDITOR

Rendi Setyo Marandi

Universitas Islam Negeri Maulana Malik Ibrahim Malang, Indonesia 
ii | P a g e

PEDOMAN TRANSLITERASI

\begin{tabular}{|c|c|c|c|}
\hline Arab & Latin & Arab & Latin \\
\hline 1 & $a$ & ض & $\mathrm{dh}$ \\
\hline ب & $\mathrm{b}$ & $b$ & th \\
\hline ت & $t$ & b & zh \\
\hline$ث$ & ts & $\varepsilon$ & 1 \\
\hline ج & $\mathrm{j}$ & $\dot{\varepsilon}$ & gh \\
\hline$\tau$ & $\mathrm{h}$ & ف & $\mathrm{f}$ \\
\hline$\dot{\tau}$ & kh & ق & $q$ \\
\hline د & d & ك & $\mathrm{k}$ \\
\hline ذذ & $\mathrm{dz}$ & J & 1 \\
\hline נ & $r$ & م & $\mathrm{m}$ \\
\hline j & $\mathrm{Z}$ & ن & $\mathrm{n}$ \\
\hline س & S & 9 & $\mathrm{~W}$ \\
\hline ش & sy & هـ & $\mathrm{h}$ \\
\hline ص & sh & ى & $\mathrm{y}$ \\
\hline
\end{tabular}


DAFTAR ISI

i

PENANGGUNG JAWAB

i

REVIEWER

i

EDITOR IN CHIEF

i

SECTION EDITOR

i

LAYOUT EDITOR

ii

PEDOMAN TRANSLITERASI

iii

DAFTAR ISI

01-12

Pembelajaran Bahasa Arab di MIN 13 Kabupaten Banjar Kalimantan Selatan

Mahmudah

Universitas Islam Negeri Antasari Banjarmasin, Indonesia

13-23

Keefektifan Model Make A Match dalam Pembelajaran Matematika Siswa Kelas VI

Sekolah Dasar di Kecamatan Marioriwawo

Andi Kaharuddin

Universitas Lakidende Unaaha, Indonesia

24-39

Konsepsi Penerapan Keterampilan Proses Sains (KPS) dan Sikap Ilmiah Dalam Desain Pengembangan Modul Panduan Eksperimen Ipa SD/MI

Ida Fiteriani ${ }^{1}$ dan Baharuddin ${ }^{2}$

1,2Universitas Islam Negeri Raden Intan Lampung, Indonesia

40-45

Pengembangan Multimedia Pembelajaran Interaktif Materi Pokok Sistem Tata Surya Untuk Siswa Kelas VI SD

Vannisa Aviana Melindaㄹ, Dimas Sambung'2, Dian Eka Aprilia Fitria Ningrum³ ${ }^{3}$ Imroatul Hayyu Erfantinni ${ }^{4}$, Roiyan One Febriani ${ }^{5}$

1,2,3,4,5Universitas Islam Negeri Antasari Banjarmasin Indonesia, Indonesia

46-52

Pengembangan Media Pembelajaran Pop-Up Berbasis Sains Kelompok B RA Raden Fatah Podorejo

Dessy Putri Wahyuningtyas ${ }^{1}$, Faizatun Na'fiah

1,2Universitas Islam Negeri Maulana Malik Ibrahim Malang, Indonesia

PEDOMAN PENULISAN

UCAPAN TERIMAKASIH

Vol. 11 No. 1, Desember 2018

Madrasah homepage: http://ejournal.uin-malang.ac.id/index.php/madrasah/index 


\title{
MADRASAH
}

Jurnal Pendidikan dan Pembelajaran Dasar

p ISSN: 1979-5599 | e ISSN: 2502-194X

P a g e

\section{KEEFEKTIFAN MODEL MAKE A MATCH DALAM PEMBELAJARAN MATEMATIKA SISWA KELAS VI SEKOLAH DASAR}

\author{
Andi Kaharuddin \\ Lakidende University of Unaaha; Jl. Hasanuddin, 082335556010 \\ andi_kaharuddin@student.smc.edu
}

DOI: $10.18860 /$ madrasah.v11i1.5563

\begin{abstract}
Abstrak. Tujuan penelitian ini adalah untuk mengetahui keefektifan model make a match dalam pembelajaran matematika siswa kelas VI Sekolah Dasar di Kecamatan Marioriwawo. Penelitian ini merupakan penelitian kuantitatif eksperimen. Populasi penelitian adalah seluruh siswa kelas VI Sekolah Dasar di Kecamatan Marioriwawo dari 50 Sekolah. Penentuan sampel dengan random sampling. Teknik analisis data yang di gunakan ialah statistika deskriptif dan statistika inferensial dengan menggunakan uji one sampel test. Hasil penelitian menunjukkan penerapan model make a match efektif dalam pembelajaran matematika kelas VI Sekolah Dasar di Kecamatan Marioriwawo ditinjau dari rata-rata hasil belajar 71,9, aktivitas 80,4\% dan respon terhadap penerapan model 93,7\%.
\end{abstract}

Kata Kunci. Keefektifan; Make a Match; Pembelajaran Matematika

Abstract. The purpose of this study was to determine the effectiveness of the model to Make a Match in mathematics learning $6^{\text {th }}$-grade students of Elementary School Marioriwawo SubDistrict. This research is a quantitative experimental research. The population in the study were all $6^{\text {th }}$-grade students of Elementary School Marioriwawo Sub-District from 50 school. Determination of the sample was done by random sampling. Data analysis techniques used is descriptive statistics and inferential statistics using a single sample test. The results showed that the application of effective models in learning mathematics $6^{\text {th }}$-grade students of Elementary School Marioriwawo Sub-District in terms of the average learning outcomes $71.9,80.4 \%$ activity and and the response to the application of the model $93.7 \%$.

Keywords. Effectiveness; Make a Match; Mathematics Learning

\begin{tabular}{ll|l} 
Received :06 September 2018 & Approved :10 Desember 2018 \\
\hline
\end{tabular}

Reviesed : 10 Desember $2018 \quad$ Published : 11 Desember 2018

Copyright (C) Madrasah Jurnal Pendidikan dan Pembelajaran Dasar. All Right Reserved.

This is an open-access article under the CC BY-NC-ND license

(http://creativecommons.org/licenses/by-nc-nd/4.0/).

Correspondence Address: andi_kaharuddin@student.smc.edu

\section{A. PENDAHULUAN.}

\section{Latar Belakang}

Perkembangan pendidikan di Indonesia tidak terlepas dari ilmu pengetahuan dan teknologi. Pendidikan merupakan bagian penting dari kehidupan masyarakat dengan tujuan membantu umat manusia khususnya masyarakat indonesia. Maksudnya, pendidikan harus mampu mewujudkan manusia seutuhnya. Dengan adanya pendidikan, diharapkan manusia mampu menyadari potensi yang ia miliki sebagai makhluk yang berakal dan berpikir. Dengan berpikir, manusia akan menemukan tujuan kehadirannya sebagai makhluk yang telah diberi akal oleh Allah SWT. Cara berfikir tersebut dijelaskan (Kaharuddin, 2013:2) berpikir melalui belajar matematika memungkinkan kita terampil berpikir rasional karena matematika 
memiliki sintaks dan hubungan yang kuat dan jelas antar konsep satu dengan konsep lainnya.

(Fauzi, Usodo, \& Subanti, 2017:2) menjelaskan bahwa pembelajaran matematika merupakan proses belajar konsep, struktur, dan batas-batas yang saling terkait untuk dipecahkan atau diselesaikan. Belajar matematika dapat melatih kemampuan berpikir kritis, kreatif dan logis. Sedangkan (Ahmad, 2015:1) menuturkan bahwa belajar matematika merupakan salah satu mata pelajaran yang sangat penting karena mata pelajaran matematika mendukung hampir semua mata pelajaran lainnya. (Lowrie \& Jorgensen, 2011:3) menambahkan bahwa pentingnya belajar matematika yang diatur dalam Standar Nasional Australia. Jadi pokok perhatian tentang belajar matematika bukan hanya didalam negeri saja tetapi diluar negeri juga.

Dari hasil wawancara sekaligus observasi dengan guru mata pelajaran matematika di beberapa Sekolah Dasar di Kecamatan Marioriwawo Kabupaten Soppeng yang tidak ingin disebutkan nama sekolahnya pada tanggal 3 Maret 2016, didapatkan informasi hasil belajar matematika pada ulangan MID Semester 2 pada tahun pelajaran 2015/2016 nilai rata-rata siswa 68,5 masih di bawah KKM yang telah ditentukan yakni 70. Ini diakibatkan karena kurangnya minat dan keaktifan siswa dalam proses pembelajaran matematika. Seperti yang di sampaikan (Lowrie \& Jorgensen, 2011:2) yaitu pokok permasalahan pertama pada pembelajaran matematika yaitu siswa seringkali dibebankan tugas tugas matematika yang belum terlalu dipahami. Dari permasalahan tersebut, alternatif pemecahan masalah yang dapat dilakukan seperti yang dikatakan (Indarti, 2016:3) adalah dengan menerapkan model pembelajaran yang lebih mengutamakan minat dan keaktifan siswa sehingga hasil belajar siswa meningkat. (Aryati, Majid, Negeri, Timur, \& Subjek, 2018:2) menjelaskan bahwa model belajar yang cocok untuk mengaktifkan siswa dan menumbuhkan gairah belajar secara berpasangan ialah model make a match. (Perdanawati, Putri, \& Gani, 2018:2) juga menegaskan keberhasilan dari setiap proses belajar ditentukan dari langkah guru dalam menggunakan model yang tepat dalam pembelajaran.

Menurut (Damopolii, 2017:3) model make a match merupakan model pembelajaran berkelompok yang menggunakan permainan mencari pasangan menggunakan kartu untuk membentuk konsep-konsep belajar. Pendapat tersebut ditambahkan (Fauzi et al., 2017:2) mengatakan bahwa model make a match sangat cocok di terapkan pada pembelajaran sekolah dasar karena memilki kelebihan yaitu siswa mencari pasangan sambil belajar tentang konsep atau topik dalam suasana yang menyenangkan. Hal yang sama dikemukakan (Irwanto \& Nurpahmi, 2017:3) yaitu dengan penerapan model make a match ini disamping membuat siswa lebih aktif juga meningkatkan pemahaman siswa dalam melihat, memperhatikan dan membaca sehingga siswa lebih interaktif dalam berkelompok. Dari beberapa pendapat diatas dapat disimpulkan bahwa model make a match merupakan salah satu model pembelajaran berkelompok yang dapat mengefektifkan proses belajar mengajar dimana siswa terlibat langsung dan menciptakan suasana pembelajaran yang lebih menyenangkan dan menghindari kejenuhan siswa dalam mengikuti kegiatan belajar mengajar.

Hasil penelitian yang dilakukan (Irwanto \& Nurpahmi, 2017:1) dari siklus I dan siklus II menunjukkan keterlaksanaan pembelajaran dan hasil belajar siswa juga meningkat drastis dari penerapan model make a match. Penelitian perbandingan yang dilakukan (Hartanti, Fidiyanti, Ruhimat, \& Winarti, 2017:1) menunjukkan bahwa model 


\section{MADRASAH}

Jurnal Pendidikan dan Pembelajaran Dasar

p ISSN: 1979-5599 | e ISSN: 2502-194X

make a match lebih baik dari pada pembelajaran konvensional ditinjau dari motivasi belajar siswa. Sedangkan hasil penelitian (Setyawati, Sukartiningsih, \& Subroto, 2018:1) menyimpulkan bahwa penerapan model make a match dalam pembelajaran dapat meningkatkan aktivitas siswa dalam pembelajaran. Dari beberapa hasil penelitin diatas diperoleh gambaran bahwa dengan penerapan model make a match dapat meningkatkan hasil belajar siswa, aktivitas siswa dalam pembelajaran dan respons siswa yang dilihat dari minat dan motivasi siswa terhadap pembelajaran.

Berdasarkan uraian, teori dan hasil penelitian relevan yang sudah dijelaskan sebelumnya, maka rumusan masalah dan tujuan dalam penelitian ini adalah melihat keefektifan model make a match dalam pembelajaran matematika siswa kelas VI Sekolah Dasar di Kecamatan Marioriwawo.

\section{B. METODE PENELITIAN}

\section{Desain Penelitian}

Jenis penelitian kuantitatif eksperimen. (Kasiram, 2008:149) mendefenisikan bahwa penelitian kuantitatif eksperimen adalah suatu proses menemukan, menganalisis dan menyimpulkan dari apa yang belum diketahui berdasarkan data atau fakta yang ditemukan. Desain penelitian ini adalah one group pretest-posttest karena diawali dengan pengukuran variabel dari satu kelompok (pretest) kemudian diberikan perlakuan dan dilakukan pengukuran kedua (posttest) terhadap variabel bebas, serta hasil pengukuran prestest dibandingan dengan hasil pengukuran posttes (Nursalam, 2003:87). Tahapan penelitian diawali dengan pretest sebelum memberikan treatment dan posttest setelah memberikan treatment atau menerapkan model pembelajaran make a match. Rancangan desain penelitian dapat dilihat pada Table 2.1 berikut.

Table B.1 Desain Penelitian

\begin{tabular}{cccc}
\hline Sekolah Dasar & Pretest & Treatment & Posttest \\
\hline SD 147 Kalempang & $\mathrm{O}_{1}$ & $\mathrm{X}$ & $\mathrm{O}_{2}$ \\
\hline
\end{tabular}

Sumber: (Sugiyono, 2013:111)

\section{Populasi dan Sampel}

Populasi adalah keseluruhan subjek penelitian. (Sugiyono, 2016, p. 25) menjelaskan bahwa populasi adalah keseluruhan wilayah generalisasi yang terdiri objek atau subjek yang memiliki nilai dan keragaman kemudian dapat disimpulkan. Populasi dalam penelitian ini adalah siswa kelas VI Sekolah Dasar di Kecamatan Marioriwawo dari 50 sekolah. SD 147 Kalempang merupakan sampel penelitian yang terpilih dari teknik random sampling dengan jumlah 30 Siswa.

\section{Metode Analisis Data}

\section{a. Analisis Deskriptif}

\section{1) Keterlaksanaan Pembelajaran}

Dari hasil observasi selama beberapa pertemuan, ditentukan nilai rata-rata kegiatan guru dari pertemuan pertama hingga pertemuan terakhir. Nilai kegiatan guru ini selanjutnya dikonfirmasikan dengan interval penentuan kategori kemampuan guru mengelola pembelajaran yang dinyatakan dalam Tabel 2.2 berikut. 
Tabel B.2 Kategorisasi Kemampuan Guru Mengelola Pembelajaran

\begin{tabular}{cc}
\hline Skor & Kriteria \\
\hline $0,00 \leq$ skor $<1,50$ & Kurang Baik \\
\hline $1,50 \leq$ skor $<2,50$ & Cukup Baik \\
\hline $2,50 \leq$ skor $<3,50$ & Baik \\
\hline $3,50 \leq$ skor $<4,00$ & Sangat Baik \\
\hline
\end{tabular}

Kriteria yang ditetapkan untuk menyatakan bahwa kemampuan guru mengelola penerapan model make a match efektif adalah apabila nilai kegiatan guru minimal berada dalam kategori "baik", berarti penampilan guru dapat dipertahankan.

\section{2) Hasil Belajar}

Data hasil belajar matematika siswa dimenjelaskan tentang nilai rata-rata, nilai maksimum, nilai minimum dan standar deviasi.

Tabel B.3 Kategorisasi hasil belajar

\begin{tabular}{cc}
\hline Skor & Kategori \\
\hline $0 \leq x \leq 59$ & Sangat Rendah \\
\hline $59<x \leq 69$ & Rendah \\
\hline $69<x \leq 79$ & Sedang \\
\hline $79<x \leq 89$ & Tinggi \\
\hline $89<x \leq 100$ & Sangat Tinggi \\
\hline
\end{tabular}

Hasil belajar siswa juga diarahkan pada pencapaian hasil belajar secara individual. Kriteria seorang siswa dikatakan tuntas belajar apabila memiliki nilai paling sedikit 70 sesuai dengan rata-rata KKM Sekolah Dasar di Kecamatan Marioriwawo, sedangkan ketuntasan klasikal tercapai apabila minimal 80\% Siswa di kelas tersebut telah mencapai skor paling sedikit 70 .

\section{3) Aktivitas}

Aktivitas siswa dikatakan berhasil jika rata-rata persentase frekuensi siswa yang melakukan aktivitas yang sesuai pembelajaran, sekurang-kurangnya $75 \%$ untuk beberapa kali pertemuan.

\section{4) Respon}

Kriteria yang ditetapkan untuk menyatakan bahwa para siswa memiliki respon positif terhadap pembelajaran matematika melalui penerapan model make a match adalah persentase respon positif untuk setiap aspek mencapai $75 \%$.

\section{b. Analisis Inferensial}

Untuk menguji hipotesis penelitian digunakan uji-t. Namun sebelum pengu-jian hipotesis, terlebih dahulu dilakukan uji prasyarat analisis yaitu uji normalitas. Kriteria pengujian yang digunakan adalah jika nilai probabilitas lebih dari $=0,05$, maka data tersebut berasal dari populasi yang berdistribusi normal, dan sebaliknya jika probabilitas lebih kecil = 0,05 maka data berasal dari populasi berdistribusi tidak normal, selanjutnya digunakan uji hipotesis dengan menggunakan uji-t one sample test. 


\section{MADRASAH}

Jurnal Pendidikan dan Pembelajaran Dasar

p ISSN: 1979-5599 | e ISSN: 2502-194X

P a g e | 17

\section{Indikator Keefektifan}

Kriteria efektivitas pembelajaran metematika dalam penelitian ini, terdiri dari tiga hal, Penerapan dari kriteria keefektifitan pembelajaran metematika dapat dilihat pada tabel 2.4 berikut:

Tabel B.4 Kriteria Keefektifitan Pembelajaran Metematika

\section{Kriteria Efektivitas}

No Pembelajaran

Syarat

Matematika

Hasil belajar siswa

1 setelah mengikuti pembelajaran

a. Terjadi peningkatan yang signifikan setelah diterapkannya model make a match. Artinya $p<a=0,05$

b. Rata-rata hasil belajar siswa memenuhi KKM yang telah ditentukan oleh pihak sekolah yaitu 70. Artinya dikatakan efektif jika nilai siswa $>70$.

c. Ketuntasan hasil belajar klasikal dikatakan efektif jika minimal $80 \%$ siswa dikelas telah mencapai skor KKM

\begin{tabular}{|c|c|c|}
\hline 2. & $\begin{array}{l}\text { Aktivitas siswa } \\
\text { dalam mengikuti } \\
\text { pembelajaran }\end{array}$ & $\begin{array}{l}\text { Aktivitas siswa dikatakn efektif jika sekurang- } \\
\text { kurangnya } 75 \% \text { siswa terlibat aktif dalam proses } \\
\text { pembelajaran }\end{array}$ \\
\hline 3. & $\begin{array}{l}\text { Respon siswa setelah } \\
\text { mengikuti } \\
\text { pembelajaran }\end{array}$ & $\begin{array}{l}\text { Respon siswa dikatakan positif (efektif) jika persentase } \\
\text { respon siswa dalam menjawab senang, menarik, dan } \\
\text { ya untuk setiap aspek mencapai } 75 \% \text {. }\end{array}$ \\
\hline
\end{tabular}

\section{HASIL DAN PEMBAHASAN}

\section{Hasil}

a. Analisis Deskriptif

1) Keterlaksanaan Pembelajaran

Data hasil analisis deskriptif keterlaksanaan pembelajaran selama tiga kali pertemuan menunjukkan. model make a match tiga kali pertemuan dapat dikategorikan "Baik" dengan skor rata-rata mencapai 3,1 atau 76,6\%.

\section{2) Hasil Belajar}

a) Pretest (sebelum perlakuan)

Hasil analisis deskriptif hasil belajar matematika siswa sebelum diberikan perlakuan dapat dilihat pada Tabel 3.1 berikut.

Tabel C.1 Hasil Belajar Matematika Siswa sebelum diberikan perlakuan

\begin{tabular}{cc}
\hline Statistik & Nilai statistik \\
\hline Ukuran sampel & 34 \\
\hline Nilai tertinggi & 80 \\
\hline Nilai terendah & 45 \\
\hline Skor ideal & 100 \\
\hline
\end{tabular}




\begin{tabular}{cc}
\hline Statistik & Nilai statistik \\
\hline Nilai rata-rata & 64,8 \\
\hline Variansi & 96,1 \\
\hline Standar deviasi & 9,8 \\
\hline
\end{tabular}

Jika perolehan skor hasil belajar matematika siswa sebelum diberi perlakuan melalui model make a match dikelompokkan ke dalam lima kategori maka diperoleh persentase skor hasil belajar yang ditunjukkan pada Tabel 3.2 berikut.

Tabel C.2 Persentase Skor Hasil Belajar Matematika Siswa sebelum diberi perlakuan

\begin{tabular}{cccc}
\hline Skor & Kategori & Frekuensi & Persentese \\
\hline $0 \leq x \leq 59$ & Sangat Rendah & 8 & 23,5 \\
\hline $59<x \leq 69$ & Rendah & 9 & 26,5 \\
\hline $69<x \leq 79$ & Sedang & 15 & 44,1 \\
\hline $79<x \leq 89$ & Tinggi & 2 & 5,9 \\
\hline $89<x \leq 100$ & Sangat Tinggi & 0 & 0 \\
\hline & & 34 & 100 \\
\hline
\end{tabular}

Berdasarkan Tabel 3.1 dan 3.2 bahwa hasil belajar matematika siswa setelah dilakukan pretest berada dalam kategori masih rendah dengan skor rata-rata 64,8 dengan standar deviasi 9,8 dan variansi 96,1. Perolehan skor untuk pretest adalah 80 untuk skor tertinggi dan 45 untuk skor terendah dari skor ideal yag mungkin dicapai yaitu 100. Kemudian, persentase ketuntasan belajar matematika siswa setelah dilakukan pretest dapat dilihat pada tabel 3.3 berikut.

Tabel C.3 Ketuntasan Hasil Belajar Matematika Siswa Sebelum diberi perlakuan

\begin{tabular}{cccc}
\hline Skor & Kriteria & Frekuensi & Persentase \\
\hline $0 \leq x<70$ & Tidak Tuntas & 17 & 50 \\
\hline $70 \leq x \leq 100$ & Tuntas & 17 & 50 \\
\hline & Jumlah & 34 & 100 \\
\hline
\end{tabular}

Dari Tabel 3.3 menunjukkan bahwa persentase ketuntasan hasil belajar siswa sebesar $50 \%$ atau 17 dari 34 orang siswa termasuk dalam kategori tuntas dan $50 \%$ atau 17 dari 34 orang siswa termasuk kategori tidak tuntas, berarti 17 orang siswa tersebut perlu remedial karena belum mencapai ketuntasan individual.

\section{b) Posttest (setelah perlakuan)}

Hasil analisis deskriptif hasil belajar matematika siswa setelah diberikan perlakuan dapat dilihat pada Tabel 3.4 berikut.

Tabel C.4 Hasil Belajar Matematika Siswa sebelum diberikan perlakuan

\begin{tabular}{cc}
\hline Statistik & Nilai statistik \\
\hline Ukuran sampel & 34 \\
\hline Nilai tertinggi & 90 \\
\hline Nilai terendah & 605 \\
\hline
\end{tabular}




\section{MADRASAH}

Jurnal Pendidikan dan Pembelajaran Dasar

p ISSN: 1979-5599 | e ISSN: 2502-194X

\begin{tabular}{cc}
\hline Statistik & Nilai statistik \\
\hline Skor ideal & 100 \\
\hline Nilai rata-rata & 71,9 \\
\hline Variansi & 46,4 \\
\hline Standar deviasi & 6,74 \\
\hline
\end{tabular}

Apabila skor hasil belajar matematika siswa dikelompokkan ke dalam lima kategori, maka diperoleh distribusi frekuensi yang ditunjukkan pada Tabel 3.5 berikut.

Tabel C.5 Persentase Skor Hasil Belajar Matematika Siswa setelah diberi perlakuan

\begin{tabular}{cccc}
\hline Skor & Kategori & Frekuensi & Persentese \\
\hline $0 \leq x \leq 59$ & Sangat Rendah & 0 & 0 \\
\hline $59<x \leq 69$ & Rendah & 6 & 17,6 \\
\hline $69<x \leq 79$ & Sedang & 23 & 67,7 \\
\hline $79<x \leq 89$ & Tinggi & 4 & 11,8 \\
\hline $89<x \leq 100$ & Sangat Tinggi & 1 & 2,9 \\
\hline & & 34 & 100 \\
\hline
\end{tabular}

Berdasarkan Tabel 3.4 dan 3.5 bahwa hasil belajar matematika siswa setelah diberi perlakuan berada pada kategori sedang dengan skor rata-rata 71,9, dengan standar deviasi 6,7 dan variansi 45,4. Perolehan skor setelah diberi perlakuan adalah 90 untuk 40 skor tertinggi dan 60 untuk skor terendah dari skor ideal yang mungkin dicapai yaitu 100. Kemudian, persentase ketuntasan belajar matematika siswa setalah diberi perlakuan dapat dilihat pada Tabel 3.6 berikut.

Tabel C.6 Ketuntasan Hasil Belajar Matematika Siswa Setelah diberi perlakuan

\begin{tabular}{|c|c|c|c|}
\hline Skor & Kriteria & Frekuensi & Persentase \\
\hline $0 \leq x<70$ & Tidak Tuntas & 6 & 17,6 \\
\hline $70 \leq x \leq 100$ & Tuntas & 28 & 82,4 \\
\hline \multicolumn{2}{|c|}{ Jumlah } & 34 & 100 \\
\hline
\end{tabular}

Dari Tabel 3.6 menunjukkan bahwa persentase ketuntasan hasil belajar siswa sebesar 82,4\% atau 28 dari 34 orang siswa termasuk dalam kategori tuntas dan 17,6\% atau 6 dari 34 orang siswa termasuk dalam kategori tidak tuntas. Hal ini dapat memberikan gambaran bahwa pelaksanaan pembelajaran matematika siswa melalui model make a match mencapai ketuntasan klasikal yaitu 80\% siswa mencapai atau lebih dari skor Kriteria Ketuntasan Minimal (KKM). Informasi lain yang ditemukan, yaitu masih ada 6 orang siswa yang memerlukan perhatian serta perbaikan secara individual pada pembelajaran matematika berikutnya.

\section{3) Aktivitas}

Hasil analisis skor aktivitas siswa pada penerapan model make a match dalam pembelajaran terlihat siswa telah terlibat secara aktif sehingga dominasi guru dalam pembelajaran dapat berkurang. Dari hasil pengamatan tampak bahwa aktivitas siswa 
yang berkaitan dengan kegiatan pembelajaran dari keseluruhan aspek yang diamati, dikatakan efektif karena rata-rata persentase aktifitas aktif siswa sama dengan rata-rata persentase komponen pertama sampai komponen kelima yaitu 80,4\%. Ini berarti bahwa siswa terlibat aktif dalam proses pembelajaran matematika melalui model tipe make a match.

\section{4) Respon}

Hasil analisis skor respon siswa terhadap penerapan model make a match diperoleh rata-rata persentase respon siswa 93,7\% sehingga dapat disimpulkan bahwa respon siswa positif terhadap pembelajaran matematika melalui model make a match karena telah memenuhi kriteria respon siswa yakni lebih besar dari 75\%.

\section{b. Analisis Inferensial}

1) Uji Normalitas

Hasil uji normalitas dengan bantuan aplikasi SPSS diperoleh nilai signifikansi untuk nilai pretest adalah nilai Sig.(2-tailed) $=0,131>0,05$, dan untuk nilai posttest adalah nilai Sig.(2-tailed)=0,075 > 0,05. Ini berarti data tersebut sudah berdistrusi normal dan sudah memenuhi syarat untuk dilanjutkan ke uji hipotesis.

\section{2) Uji Hipotesis}

Hasil uji hipotesis dengan pengujian one sample test dapat dilihat dibawah ini

a) $H 0$ : Rata-rata hasil belajar siswa setelah diterapkannya model make a match siswa belum mencapai KKM yaitu 70 .

$H 1$ : Rata-rata hasil belajar siswa setelah diterapkannya model make a match siswa telah mencapai atau melebihi KKM yaitu 70.

b) Dipilih taraf signifikansi a $=0,05$

c) Daerah Kritis

Menolak $H 0$ apabila $a>$ Sig. (2-tailed). Karena Sig. (2-tailed) =0,004 $>a=0,05$, maka $H 0$ ditolak atau $H 1$ diterima. Dengan kata lain, rata-rata hasil belajar siswa setelah diterapkannya model make a match pada siswa telah mencapai atau melebihi KKM yaitu 70 .

\section{Pembahasan}

Dari penerapan model make a match dalam pembelajaran matematika siswa diperoleh persentase hasil belajar siswa mencapai ketuntasan secara klasikal yaitu $82,3 \%$ atau 28 dari 34 orang siswa telah mencapai kriteria ketuntasan minimal, dengan skor rata-rata 71,9 , dan standar deviasi 6,7. Ini berarti siswa yang telah mencapai ketuntasan individual setelah penerapan model make a match lebih banyak dibanding siswa yang telah mencapai ketuntasan individual sebelum diterapkannya model $a$ match.

Hasil analisis inferensial dengan program SPSS, pada hipotesis diperoleh signifikansi < $a$ yaitu 0,004, dimana $a=0,05$. Hal ini berarti, rata-rata hasil belajar siswa setelah diterapkannya model make a match pada siswa mencapai nilai KKM yaitu 70.

Dengan menggunakan model make a match dalam pembelajaran, aktivitas dan interaksi baik antar guru dengan siswa maupun antara siswa dengan siswa yang lain meningkat. Hal ini disebabkan karena pembelajaran dilakukan dengan bentuk kegiatan siswa bekerja dan mengalami untuk memperoleh pengetahuan mereka. Siswa menyelidiki sendiri, menemukan permasalahan, kemudian menyelesaikan 


\section{MADRASAH}

Jurnal Pendidikan dan Pembelajaran Dasar

p ISSN: 1979-5599 | e ISSN: 2502-194X

P a g e

permasalahan dibawah petunjuk fasilitator (guru). Proses pembelajaran seperti ini menekankan keterlibatan siswa untuk aktif berinteraksi sehingga mereka dapat mengkonstruksi pengetahuannya sendiri. Hal ini sesuai dengan teori konstruktivisme (Suprijono, 2013:39) menyatakan bahwa dengan bekerja secara kooperatif dapat menumbuhkan kemampuan kolaboratif dalam menemukan konsep baru. Keterlibatan dengan orang lain membuka kesempatan bagi siswa untuk memperbaiki pemahaman mereka saat mereka bertemu dengan pemikiran orang lain. Dengan demikian, pembelajaran dengan menggunakan model make a match juga berupaya mengaktifkan siswa belajar dengan mengupayakan timbulnya interaksi yang baik di dalam kelas.

Selain hasil belajar matematika yang diperhatikan dalam penerapkan model make a match, terdapat aspek lain yang menjadi pengamatan dalam penelitian ini yaitu aktivitas siswa selama proses pembelajaran berlangsung, keterlaksanaan pembelajaran, serta respon siswa terhadap pembelajaran matematika dengan model make a match.

Aktivitas siswa yang berkaitan dengan kegiatan pembelajaran dari aspek yang diamati secara keseluruhan dikategorikan efektif. Hal ini ditunjukan dengan rata-rata aktivitas aktif siswa terhadap pembelajaran mencapai $80,4 \%$. Siswa antusias dalam mengikuti pembelajaran matematika dengan menggunakan model make a match dan menunjukkan aktivitas aktif dalam kelompok. Hal ini disebabkan karena dalam proses pembelajaran siswa merasa mendapat tantangan baru dari masalah-masalah yang diberikan di awal pembelajaran.

Keterlaksanaan pembelajaran dari penerapan model make a match secara umum juga dikategorikan baik. Hal ini dapat dilihat dari hampir seluruh aspek yang diamati terlaksana dengan baik dalam proses pembelajaran, meskipun dalam penelitian ini keterlaksanaan pembelajaran bukan sebagai indikator keefektifan, namun tetap diamati untuk mengetahui kemampuan guru melaksanakan fase-fase pembelajaran selama proses belajar mengajar berlangsung, oleh karena itu keterlaksanaan pembelajaran merupakan sesuatu yang tidak kalah pentingnya untuk diamati. Adapun respon siswa terhadap penerapan model make a match dalam pembelajaran matematika pada umumnya memberikan tanggapan positif. 53

Berdasarkan pembahasan yang telah diuraikan di atas, maka dapat disimpulkan bahwa terjadi peningkatan atau perubahan secara signifikan terhadap hasil belajar matematika siswa setalah diterapkannya model pembelajaran make a match, rata-rata hasil belajar siswa setelah diterapkan model make a match pada pembelajaran matematika mencapai nilai KKM yaitu 70, hasil belajar matematika siswa tuntas secara klasikal, aktivitas siswa yang berkaitan dengan kegiatan pembelajaran mengalami peningkatan, respon siswa terhadap pembelajaran matematika melalui model make a match positif, dan kemampuan guru (keterlaksanaan pembelajaran) mengelola pembelajaran melaui model make a match masuk dalam kategori baik. Dengan demikian dapat disimpulkan bahwa penerapan pembelajaran matematika melalui model make a match dalam pembelajaran matematika efektif digunakan pada siswa kelas VI Sekolah Dasar di Kecamatan Marioriwawo.

\section{KESIMPULAN}

Berdasarkan hasil penelitan dan pembahasan yang telah dijelaskan sebelumnya, maka dapat disimpulkan bahwa penerapan pembelajaran matematika melalui model 
make a match dalam pembelajaran matematika siswa kelas VI Sekolah Dasar di Kecamatan Marioriwawo efektif ditinjau dari hasil belajar siswa setelah pembelajaran 71.9 , aktivitas siswa dalam pembelajaran $80.4 \%$ dan respon siswa terhadap penerapan model $93.7 \%$.

\section{REFERENSI}

Ahmad, H. (2015). Peningkatan Partisipasi dan Hasil Belajar Peserta Didik Pada Materi Operasi Aljabar Melalui Model Pembelajaran Kooperatif Tipe Make A Match di Kelas Viii C Smp Negeri 1 Malunda, 9(1), 62-71.

Aryati, D., Majid, A., Negeri, S. M. A., Timur, K., \& Subjek, I. (2018). Pengaruh penggunaan model pembelajaran make a match dalam model pembelajaran team Games Tournament terhadap hasil belajar siswa SMA pada pokok bahasan tata nama senyawa. Pengaruh penggunaan model pembelajaran make a match dalam model pembelajaran team games tournament terhadap hasil belajar siswa sma pada pokok bahasan tata nama senyawa, 1(1), 1-4. Retrieved from http://jurnal.fkip.unmul.ac.id/index.php/bivalen\%0APENGARUH

Damopolii, I. (2017). Pengaruh Model Pembelajaran Kooperatif Tipe STAD Berbantuan Media Pembelajaran Komik IPA Terpadu terhadap Peningkatan Hasil Belajar Siswa. https://doi:10.31227/osf.io/8qewt

Fauzi, M. N., Usodo, B., \& Subanti, S. (2017). The Effect Of Make A Match ( MAM ) Type Model and Bamboo Dance Type Model Through Cooperative Learning on Students Motivation, 3(1), 27-32. https:/ / doi.org/10.1002/chem.201204594

Hartanti, H., Fidiyanti, N., Ruhimat, M., \& Winarti, M. (2017). Effect of Implementation of Cooperative Learning Model Make A Match Technique on Student Learning Motivation in Social Science Learning (Quasi Experimental Class VIII SMP Negeri 40 Bandung).

Indarti, C. (2016). Pembelajaran IPS melalui model cooperative learning dengan teknik make a match untuk meningkatkan hasil belajar siswa kelas IV SDN Tiron 02. Pembelajaran IPS melalui model cooperative learning dengan teknik Make a Match untuk meningkatkan hasil belajar siswa kelas iv sdn tiron 02, 1(1), 52-59. Retrieved from http:/ / e-journal.ikippgrimadiun.ac.id/index.php/gulawentah\%0APendahuluan

Irwanto, \& Nurpahmi, S. (2017). Using make- a match to improve the students' reading comprehension at mts guppi samata gowa. Using Make- a Match to Improve the Students' Reading Comprehension at Mts Guppi Samata Gowa, 3(02), 161-172.

Kaharuddin, A. (2013). Effectiveness Comparative of Scientific Approach Elpsa and Open-Ended Setting Cooperative Stad Types of Mathematics Learning At ViI Class SMP Negeri of A Accreditation in Makassar. Jurnal daya matematis, 1(1), 29-42. https://doi.org/http:/ / dx.doi.org/10.26858/jds.v1i1.3307

Kasiram, M. (2008). Metode Penelitian Kuantitatif-Kualitatif. UIN-Malang Press, Malang.

Lowrie, T., \& Jorgensen, R. (2011). Gender differences in students' mathematics game playing. Computers and Education, 57(4), 2244-2248. https://doi.org/10.1016/j.compedu.2011.06.010

Nursalam, K., \& Keperawatan, P. M. P. I. (2003). Pedoman Skripsi (Doctoral dissertation, Tesis dan Instrumen Penelitian). Jakarta: Salemba Medika.

Perdanawati, E., Putri, K., \& Gani, A. (2018). Effect of Cooperative Make a Match Learning Model on Student's Learning Outcomes on Electrolyte and Non- 


\section{MADRASAH}

Jurnal Pendidikan dan Pembelajaran Dasar

p ISSN: 1979-5599 | e ISSN: 2502-194X

P a g e | 23

Electrolyte Solutions Topics, 174(Ice 2017), 134-137.

Setyawati, R. T., Sukartiningsih, W., \& Subroto, W. T. (2018). Make and match method supported by picture media to improve student s ' learning activity, 173(Icei 2017), 276-279.

Sugiyono. (2013). Metode Penelitian Kuantitatif Kualitatif dan R \& D. Bandung: Alfabeta Sugiyono. (2017). Metode Penelitian Kuantitatif, Kualitatif, dan RED. Bandung: Alfabeta Suprijono, A. (2013). Cooperative learning: teori \& aplikasi PAIKEM. Pustaka Pelajar 


\section{PANDUAN PENULISAN \\ MADRASAH: JURNAL PENDIDIKAN DAN PEMBELAJARAN DASAR \\ FAKULTAS ILMU TARBIYAH DAN KEGURUAN \\ UNIVERSITAS ISLAM NEGERI MAULANA MALIK IBRAHIM MALANG}

\section{Umum}

1. Karya ilmiah harus asli, belum pernah dipublikasikan di media lain, atau sedang dalam proses review untuk diterbitkan di publikasi lain (melampirkan surat pernyataan).

2. Menggunakan Bahasa Indonesia atau Bahasa Inggris* (*Pastikan penulisan dengan Bahasa Inggris sesuai kaidah yang berlaku, dan disubmit online melalui http://ejournal.uin-malang.ac.id/index.php/madrasah, kami tidak bertanggung jawab jika artikel anda tidak mendapat respon dari reviewer)

3. Menggunakan kertas A4 $(21 \mathrm{~cm} \times 29.7 \mathrm{~cm})$, dengan margin kiri $2.5 \mathrm{~cm}, 2 \mathrm{~cm}$ kanan, $2 \mathrm{~cm}$ bawah, $2 \mathrm{~cm}$ atas.

4. Jumlah paper minimal 7 halaman, maksimal 16 halaman kecuali ada lampiran, toleransi maksimal 20 halaman dengan 1 spasi dan alignment justify.

5. Font yang digunakan Book Antiqua 12 pt dan Sakkal Majalla (Jika ada konten Bahasa Arab) 14 pt.

6. Disarankan menggunakan referensi yang terbaru 10 tahun terakhir, kecuali kitab klasik.

7. Format file menggunakan Mic. Office/open Office (disarankan office 2013/2016_ dengan eksistensi RTF bukan PDF.

\section{Kontent Naskah}

1. Judul maksimal 15 kata, alignment center.

2. Nama penulis tidak menggunakan gelar, mencantumkan institusi, dan email.

3. Abstrak minimal $150 \mathrm{kata}$ dan maksimal $300 \mathrm{kata}$, satu paragraph, tidak terdapat tabel dan gambar.

4. Keywords minimal 3 kata dan maksimal 5 kata, dipisahkan dengan tanda titik koma $(;)$.

5. Sistematika penulisan: Judul, Abstrak, Kata Kunci, Pendahuluan, Metode, Hasil, Pembahasan, Simpulan dan Saran, Pernyataan Terima Kasih (jika ada), Daftar Rujukan. Selain hasil riset, menyesuaikan dengan format penulis.

6. Format Tabel (Bold). Jika terdapat tabel, jarak antara row adalah 1 spasi, pada kategori tabel huruf ditebalkan (bold), dan penulisan sumber setelah tabel terakhir. Jika tabel bersambung ke halaman berikut blok row kategori tabel dengan kemudiak klik layout $=>$ repeat header rows seperti format tabel A.1.

Tabel A.1 Judul Tabel (justify)

(1 spasi)

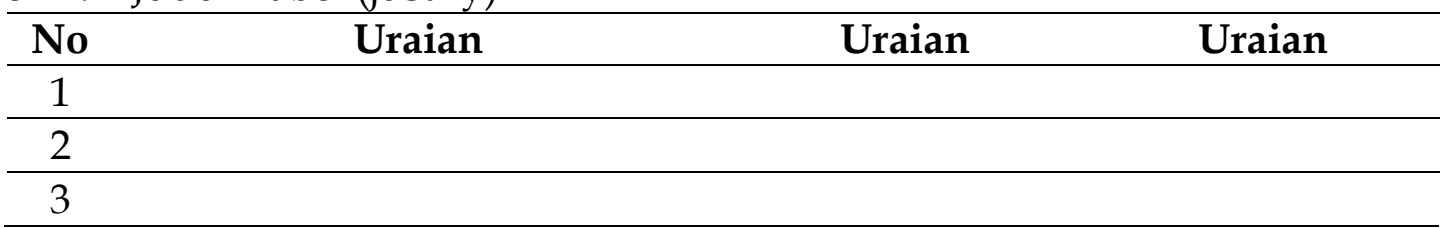

Sumber: 


\section{Format Gambar}

Jika terdapat gambar, grafik, diagram, dan yang serupa gunakan format dan wrap text gambar $=>$ in line with text atau menggunakan fitur text box, untuk kestabilan terhadap perubahan format dan pergesaran. Jarak antara kalimat terakhir dan sesudah gambar adalah 1 spasi. Gambar posisi center (tengah) seperti gambar A.1. (1 spasi)

Gambar A.1 Judul Gambar (center)

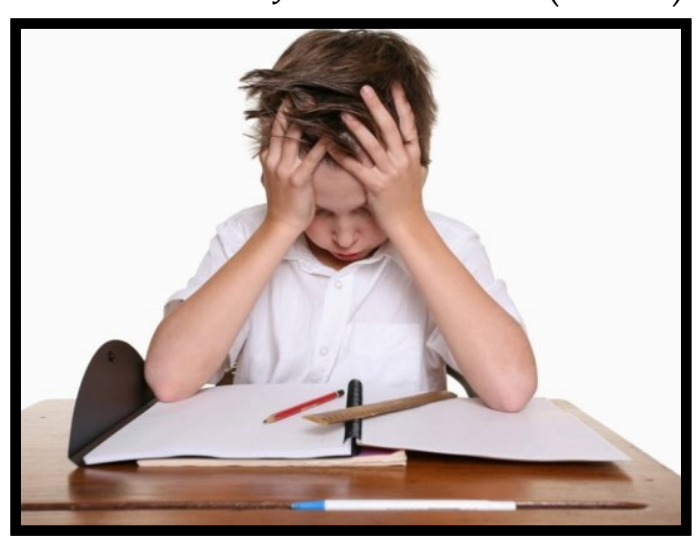

Sumber: (center)

(1 spasi)

\section{Format Numberring}

Pada jurnal Madrasah tidak diperkenankan menggunakan Bullet hanya Numberring, kecuali termasuk dalam penulisan rumus. Numbering menggunakan format Huruf dan Angka. Dimulai dari Huruf kemudian Angka seperti format berikut.

Format Numbering:

A.

1.

2.

a.

b.

1)

2)

a)

b)

B.

C.

9. Daftar Kutipan dan Rujukan menggunakan format APA 6 $^{\text {th }}$ Style Edition. Disarankan menggunakan aplikasi referensi seperti Zotero, Mandeley, Endnote, dan sebagainya.

10. Sebelum mengirim naskah, disarankan untuk melakuken cek typographical dan grammatical errors serta cek plagiat, bisa melalui.

a. Grammarly: www.grammarly.com 
b. Turnitin: http://turnitin.com/

11. Contatc:
a. Website : http://ejournal.uin-malang.ac.id/index.php/madrasah
b. Email : madrasah@uin-malang.ac.id
c. Editor in Chief: M. Irfan Islamy (085390790907)

\section{Author Fees}

This journal charges the following author fees.

Article Submission: 0 (IDR)

Fast-Track Review: 0 (IDR)

Article Publication: 0 (IDR)

Open Donations:

\section{Copyright Notice}

Madrasah: Jurnal Pendidikan dan Pembelajaran Dasar

\section{Privacy Statement}

The names and email addresses entered in this journal site will be used exclusively for the stated purposes of this journal and will not be made available for any other purpose or to any other party. 
UCAPAN TERIMAKASIH

KEPADA PARA REVIEWER, EDITOR, DAN PENULIS ATAS TERBITNYA MADRASAH: JURNAL PENDIDIKAN DAN PEMBELAJARAN DASAR VOLUME 11 NOMOR 1 DESEMBER 2018 